\section{Contextualising the National Development Plan for enhanced service delivery: Considerations for planning in KwaZulu-Natal}

\author{
Mogie Subban \& Henk Theron
}

http://dx.doi.org/10.18820/2415-0495/trp68i1.4

Peer reviewed and revised

\begin{abstract}
Integrated Development Plans (IDPs) are the planning instruments directed at strategies for enhancing service delivery in local government. As a consequence, capacity initiatives are driven by these plans to address prioritised developmental needs. The key to establishing such initiatives is informed by the National Development Plan (NDP). This Plan changed the planning regime in South Africa, culminating in a comprehensive planning hierarchy for local, provincial and national spheres of government. In light thereof, the paper theoretically examines the alignment of planning work procedures in KwaZulu-Natal (KZN) in ensuring that development planning is 'on track'. To this end, the KZN Provincial Planning Commission (PPC) developed a Provincial Growth and Development Strategy (PGDS) aligned with the National Plan. It follows then that District Municipalities formulated a District Growth and Development Plan (DGDP) with the same time horizon as the National Plan leading to 2030. Municipal Integrated Development Plans (IDPs) then become instruments to implement the Provincial Strategy in five-year periods. Against the background of action-based Batho-Pele Principles as necessary determinants, key issues may be addressed, whilst contextualising long-term development planning and implementation as the NDP-PGDP-IDP praxis. Cumulatively, planners in KZN must respond to this new plan hierarchy innovatively by integrating and aligning with the NDP at other planning levels in an ethical, accountable and socially responsible manner addressing poverty, inequality and unemployment. The article concludes that the trajectory of development planning in $\mathrm{KZN}$ is strategically linked to national and long-term initiatives and work procedures for enhanced service delivery.
\end{abstract}

Key words: National Development Plan, Provincial Growth and Development Strategy, Integrated Development Planning, enhanced service delivery

\section{KONSEPTUALISERING VAN DIE NASIONALE ONTWIKKELINGSPLAN VIR VERBETERDE DIENSLEWERING: OORWEGINGS VIR BEPLANNING IN KWAZULU-NATAL}

Geïntegreerde Ontwikkelingsplanne (GOPPE) is die beplanninginstrumente wat strategieë vir die bevordering van dienslewering op plaaslike regeringsvlak bevat. Gevolglik word kapasiteitsinitiatiewe deur hierdie planne uiteengesit om geprioritiseerde ontwikkelingsbehoeftes aan te spreek. Die sleutel vir die totstandbring van sulke inisiatiewe is in die Nasionale Onwikkelingsplan (NOP) te vinde. Die Plan het die beplanningsraamwerk in Suid-Afrika verander om sodoende 'n omvattende beplanningshiërargie vir plaaslike, provinsiale en nasionale regeringsvlakke daar te stel. Teen hierdie agtergrond, teoretiseer die artikel oor die belyning van beplanningswerksprosedures in KwaZulu-Natal (KZN) om te verseker dat ontwikkelingsbeplanning 'op die regte spoor is'. Gevolglik het die KwaZulu-Natalse Provinsiale Beplanningskommissie (PBK)'n Provinsiale Groei-en Ontwikkelingstrategie (PGOS) ontwikkel, wat in lyn is met die nasionale plan. Dit word gevolg deurdat distriksmunisipaliteite Distriksgroei- en Ontwikkelingsplanne (DGOPe) opgestel het, wat dieselfde tydshorison van 2030 het as dié van die NOP. Die instrumente om die DGOPe te implementer, is die GOPPE van munisipaliteite, wat 'n vyf jaar lewensduur het. Teen die agtergrond van noodsaaklike aksie-gedrewe Batho Pelebeginsels kan sleutelvraagstukke binne die langtermyn beplanning en implementering van die NOP-DGOP-GOP raamwerk aangespreek word. Beplanners in KZN moet innoverend en gesamentlik op hierdie nuwe beplanningshiërargie reageer deur integrering en belyning met die NOP op alle beplanningsvlakke op 'n etiese, toerekeningsvatbare en sosiaal verantwoordelike manier om sodoende armoede, ongelykheid en werkloosheid aan te spreek. Die artikel sluit af met die gevolgtrekking dat die ontwikkelingstrajek van ontwikkelingsbeplanning in KZN strategies met die nasionale en langtermyn inisiatiewe en werksprosedures vir verbeterde dienslewering verbind is.

Sleutelwoorde: Nasionale Ontwikkelingsplan, Provinsiale Groei- en Ontwikkelingstrategie, Geïntegreerde Ontwikkelingsplanne, verbeterde dienslewering

USAUKANYA PLANE YA SHANGO LA AFRIKA TSHIPEMBE (NDP) HUUITELA U KHWINISA NDISEDZO YA TSHUMELO LUSHAKANI NGA VHUPULANI KWAZULU-NATAL

Integrated Development Plans (IDPs) ndi zwishumiswa zwo pikwaho ukhwinisa ndisedzo yatshumelao nga mivhuso yapo. Ngauralo, dzithandela dza umandafhadza dzi ndisedwa nga idzi plane hu uitela $u$ fhelisa thodea dza mveledziso dzo tiwaho. Zwihulwane u tumbulwani ha idzothandela, ndi khwathisedzo ibvaho kha Plane Khulu ya Afrika Tshipembe(NDP) ine yoshandukisa ndila yau pulana Afrika Tshipembe. Hezwo zwotou tutuwedza ngau angaredza mitevhe yavhupulani ineyavha mivhuso yapo, ya vundu naya ntha ha ya vundu. Ngau dodombedza, heyi gandiso ithathuvha vhutumani ha ndila dza vhupulani kha vundu la KwaZulu-Natal ukhwathisedza uri vhupulani ha mvelaphanda vhukhou bvelaphanda. Uswika zwino, khomishini ya vhupulani ya vundu la KwaZulu-Natal (KZN) yo bveledzisa plane ya u alusa vundu (PGDS) yo di sendekaho nga pulane khulwane ya Afrika Tshipembe. Itevhelwa nga pulane dzamivhuso ya

The authors declared no conflict of interest for this title and article.

Dr Mogie Subban, Senior Lecturer: Discipline Public Governance, School of Management, Information Technology \& Governance, College of Law \& Management Studies, University of KwaZulu-Natal, University Road, Westville, 3630, South Africa. Phone: +27 260 7763 , Mobile: 0823734393, email: <subbanm@ukzn.ac.za>

Dr Henk Theron, Chief Town and Regional Planner: IDP Co-ordination, KwaZulu-Natal Department of Co-operative Governance and Traditional Affairs, 271 Church Street, Pietermaritzburg, 3200, South Africa. Phone: +27 33355 6431, Mobile: 079 227 0827, email: <henk.theron@kzncogta.gov.za> 
ntha yapo (DGDP) yobadekanwaho na pulane khulwane yo pimelwaho uswika nga nwaha wa 2030. Pulane dza mivhuso yapo (IDPs) ngauraro dzi vha zwishumiswa zwau implimentha pulane ya vundu nga minwaha mitanu(5). Hezwo azwi ngo thudzela kule dzi tenwa zwa Batho-Pele saizwi zwi tshi tandulula dzikhaedu khulwane nau dzeula pulane ya tshifinga tshilapfu ya mveledziso na $\mathrm{u}$ implimenthwa ha NDP-PGDP-IDP. Ngauralo, vhapulani vha KZN tevhela mitevhe iyo ngavhukoni, tanganyisa, na $u$ ubadekanya kha mivhuso yothe ya Afrika tshpembe ngaufhulufhedzea, udzhiela zhele na vhudifhinduleli tshitshavhani. Zwothe zwi kwinisa vhushayi, ndinganyiso, nau shayiwa ha mishumo sa zwo tiwaho nga pulane ya tshifhinga tshilapfu. Heyi gandiso ikhunyeledza ngauri, mutalambalo wa vhupulani ha mbvela phanda $\mathrm{KZN}$ ho dzudzanyea nau badekanywa na dzi thandela dza khulwane na maitele a $u$ khinisa ndisedzo ya tshumelo.

Maipfi dendele: Pulane ya muvhuso wa Afurika Tshipembe, Pulane ya Bveledzisa vundu, Pulane ya ndisdzo ya Tshumelo, Ndiseszo ya Tshumelo yo khwiniswaho

\section{INTRODUCTION}

According to Friedmann (in Drewes \& Van Aswegen 2013: 21), "planning is primarily a way of thinking about social and economic problems, is oriented predominantly towards the future, deeply concerned with the relation of goals to collective decisions and strives for comprehensiveness in policy and program". Against this background, it is essential to locate the discussion and discourse on development planning in the South African context against the current sociopolitical realities. The challenge of implementation for tangible outcomes-based delivery is an important focal point emphasised by the authors.

Penderis (2012: 7) proffers that there is a vast body of literature that calls for a new type of developmental state in South Africa, anchored by principles of democracy, citizen participation, human rights and social inclusion. In lieu of the nation's exclusionary past, a South African developmental state must be underpinned by democratic principles, with a strong transformative thrust. Edigheji (in
Penderis, 2012: 7) agrees, stressing that a South African developmental state must move beyond the narrow confines of electoral democracy and ensure citizens' participation in the development and governance processes. This author calls for bringing "citizenship back into politics" for meaningful development, equal opportunity, and economic justice. Penderis (2012: 12) shares that the successful developmental state is dependent on the quality of leadership and developmental commitment and vision, as emphasised in the National Development Plan (NDP), 2030.

Late Minister Roy Padayachie, Minister of Public Service and Administration, argued that, in order to construct a developmental state in South Africa, it should be democratic, but also root out poverty, deliver quality services, fight corruption, improve access to quality education, ensure economic growth, and create more jobs in the economy (Padayachie, 2012: 44, 48). According to Lukhele (2015: 776), it is stated that the broader developmental policy objective of improving the quality of life of the people is captured in the National Spatial Development Perspective (NSDP) (2006) with a normative set of principles as a guiding policy framework for economic, social and spatial development planning in the country. Following on, the NDP, therefore, places us on a forwardlooking trajectory and requires all of us, not only Government, to commit to concrete programmes improving the lives of all South Africans.

\section{THEORISING INTEGRATED DEVELOPMENT PLANNING VIS-À-VIS BATHO PELE PRINCIPLES}

In theorising integrated development planning for social upliftment, the quality of service delivery is enhanced through the Principles of Batho Pele, aptly captured and paraphrased from Muller (2012: 2), as "integrated development planning theory without practice is sterile; practice of Batho Pele Principles without development theory is blind" is a useful connect for social upliftment of local communities, maintains the author. Integrated development planning is, therefore, regarded as a strategic approach to providing access to important principles of service delivery, as outlined in the White Paper on Transforming Public Service Delivery (Batho Pele White Paper) of 1997 (RSA, 1997). The White Paper, in light thereof, provides a policy framework and a practical implementation strategy for the transformation of public service delivery.

Emanating from the above discussion is the NDP as the long-term strategic framework for service delivery in South Africa.

\section{FORMULATION AND ADOPTION OF THE NATIONAL DEVELOPMENT PLAN, 2030}

A national plan can be identified as "a government economic plan which lays down the proposed pattern of economic development (investment, production, and consumption levels) over a number of years to come", according to Goodall (in Drewes \& Van Aswegen, 2013: 22). The 2030 Plan and Vision for South Africa is intended to play a larger role than conventional policy in helping forge a new social impact and commitment from all sectors of society to channel collective action towards social issues and development to the wider benefit of society at large, maintains Powell (2014: 9).

The main argument of the National Planning Commission (NPC) regarding the need for a national plan is the urgency to address the poverty cycle and exclusion of the majority of people from opportunities for further education. The NDP aims at creating a virtuous cycle whereby opportunities are expanded, leading to building capabilities of the nation, resulting in a reduction in poverty and community development, and ultimately giving rise to higher living standards and expanding opportunities for a new generation.

At the core of the NDP lies the need for growth and development to be supported by interested, focused and 
determined leadership, a capable state and sacrifice on all levels of participation. As such, the Plan aims to gain national consensus and social cohesion. In terms of physical spatial planning, the NDP proposes the development of a National Spatial Framework (NSF) involving government, business and civil society to create a collective vision. According to the NDP, the proposed NSF should target a number of spatial areas, viz. a national competitiveness corridor; nodes of competitiveness; rural restructuring zones; resource-critical regions; transnational development corridors, and special intervention areas, cohere Drewes and Van Aswegen (2013: 25).

Drewes and Van Aswegen (2013: 25) further summarise that policies and national planning initiatives can be meaningfully evaluated according to the principles of economic and spatial applications, as well as the government's implementation approach, as evidenced in this article. The aim is not to reduce a very complex and serious issue to something trivial, but rather to give an overview of the strategic intent of Government over time. Ultimately, the discussion in its entirety serves as a tool to assist in understanding the enormous impact of 36 years of national spatial planning.

The South African National Government appointed the NPC in May 2010 to draft a vision and national development plan (NDP 2030, Executive Summary: 15). The Commission's Diagnostic Report was released in June 2011. The Report determined nine primary challenges, including that too few people work, infrastructure is poorly located, inadequately and undermaintained, and spatial divides impede inclusive development. Upon further consultation, the draft NDP was released in November 2011 for comments by the public at large.

In short, the NDP aims to eliminate poverty and reduce inequality substantially, as measured by the Gini coefficient from 0.69 to 0.6 (NDP 2030, Executive Summary: 24). The intention is to achieve overall goals, including

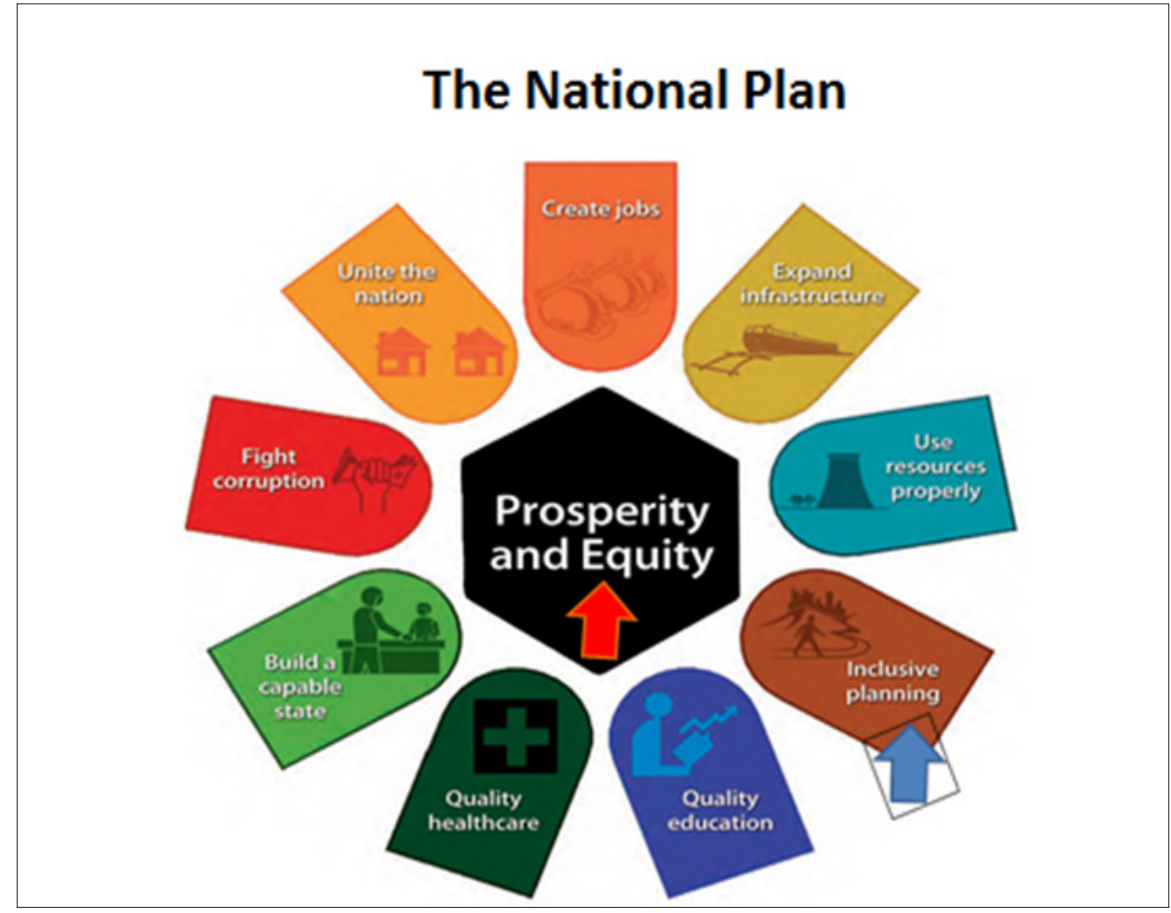

Figure 1: The National Plan

Source: KZN COGTA, 2014: Presentation

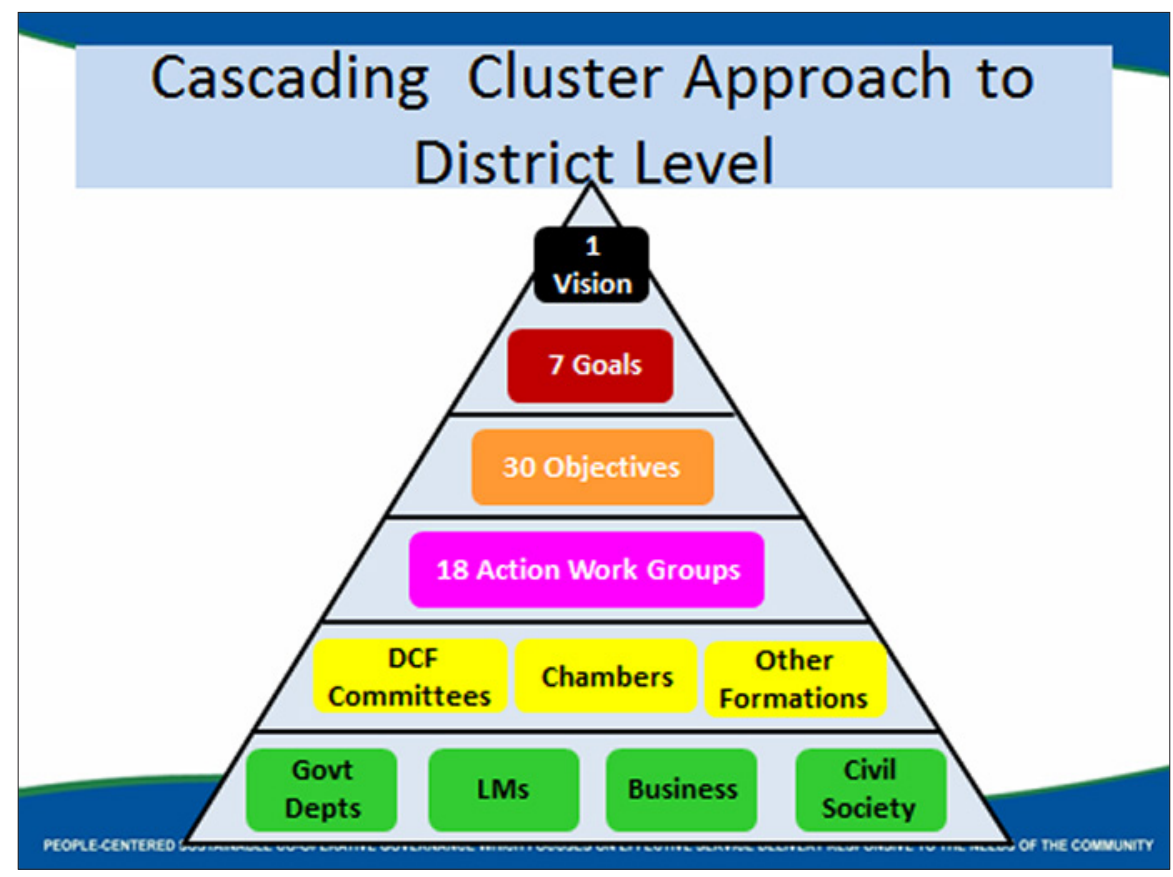

Figure 2: KZN implementation of NDP in a schematic form Source: KZN COGTA, 2014: Presentation

infrastructure development and development of a capable and ethical state. Critical actions to be taken are to professionalise the public service, strengthen accountability, and improve co-ordination with new spatial norms and standards (NDP 2030, Executive Summary: 24). In 2012, Parliament adopted the NDP with the view that provinces had to commence formulating their own plans in order to implement the NDP, as illustrated in Figure 1.

Following on the National Plan which sets the 'tone' for the planning terrain in the long term, is the illustration of the KZN plan couched within the NDP in Figure 2 which focuses on significant aspects of the vision, goals, objectives, work groups, and key stakeholders. 
Figure 2, therefore, demonstrates the hierarchical nature of how all stakeholders are organised and represented in the 18 Action Work Groups (AWGs) that develop programmes and projects to implement the 30 objectives that informed the seven Provincial goals and the KZN Provincial vision. The 18 AWGs are important in regularly monitoring the implementation of the Provincial Growth and Development Strategy (PGDS) programmes and projects.

This article then argues the cascading relationship between the NDP-PGDS-IDP, whereby development planning work procedures entail comprehensive planning in accordance with the strategic vision of the NDP for enhanced service delivery, and is contextualised within the KZN Province.

The KZN PGDS aims to be the implementation instrument for the NDP 2030 time-span. The Plan was developed in 2011 after in-depth consultation of stakeholders and adopted by the KZN Provincial Cabinet even before the finalisation of the NDP. Upon the finalisation of the NDP, the KZN PGDS was aligned with the NDPs policies and programmes to achieve the National 030 Vision. In KZN at least, this is contrary to Terreblanche's (2014: 150) position during which it was asked who would be responsible for the implementation of the policy measures that are needed to be achieved by the over optimistic NDP goals.

\section{KWAZULU-NATAL PROVINCIAL GROWTH AND DEVELOPMENT STRATEGY, 2011}

The vision of the 2011 KwaZulu-Natal Provincial Growth and Development Strategy (KZN PGDS) bolsters the Province's commitment to achieving its focus for KZN as a "Prosperous Province with a healthy, secure and skilled population, acting as a gateway to Africa and the World". The PGDS aims to build this gateway by growing the economy for the development and improvement of the quality of life of all people living in the province. Whilst the Provincial Government of $\mathrm{KZN}$ is leading this process, its success still depends on strong contacts with labour, civil society and business organisations (KZN-PPC, 2011: 6).

The PGDS states that, by 2030 , KZN Province should have maximised its position, as well as its human and natural resources so as to create a safe, healthy, and sustainable living environment. Abject poverty, inequality, unemployment, and the current disease burden should be addressed with the provision of basic services for all people. The document advances the Batho Pele principle of putting people first and where leadership, partnership and prosperity in action has become a normal way of life (KZN-PPC, 2011: 6). Figure 3 demonstrates how the NDP is cascaded down from a national plan or vision to ward-based plans in order to give effect of the vision on a local level (KZN Office of the Premier, Presentation, KZN key priorities for the term 2014/19 towards 2030, 25 August 2014).

The focus and emphasis, as set out in the diagram below, is on how the NDP and KZN PGDS are strategically linked and inform each other to ensure that the NDP's vision is implemented via the PGDS, DGDPs, IDPs and Ward Plans as a significant inter-relationship for improving work plans and procedures and service delivery enhancement.

\section{LOCUS AND FOCUS OF THE NATIONAL DEVELOPMENT PLAN AND KWAZULU-NATAL'S PROVINCIAL GROWTH AND DEVELOPMENT STRATEGY}

The backdrop to the 2011 KZN PGDS is the 6 Provincial Priorities, 12 National Outcomes, the New Growth Path, the NPCs Diagnostic Report, and the Millennium Development Goals (MDGs). These policies collectively, the PGDS Situational Overview Report and the strategic analysis provide the foundation for the $2011 \mathrm{KZN}$ PGDS and set the scene for the province to further build on these key priorities in developing its own growth and development trajectory (KZN-PPC, 2011: 7-8).

Notwithstanding the successes to date, there is widespread acknowledgement within the Province that continuing with a 'business-as-usual' approach will not bring about required growth and development that is necessary

\section{Priorities guided by alignment of Strategic Plans}

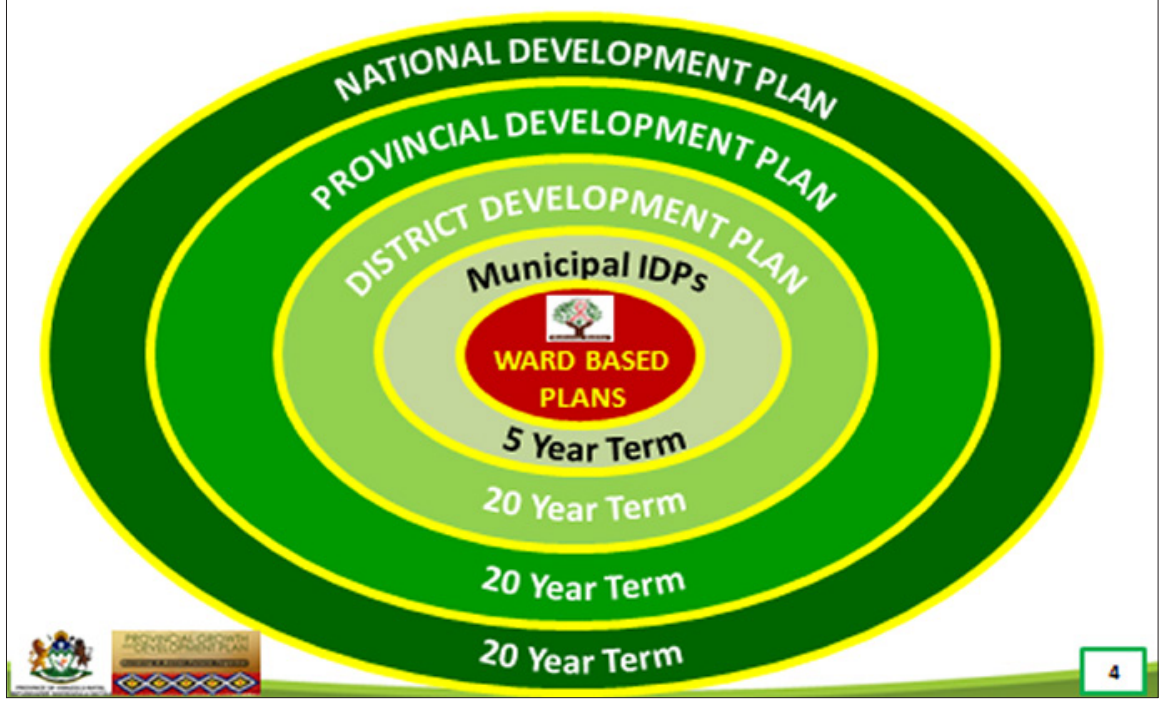

Figure 3: Priorities guided by alignment of strategic plans

Source: KZN Office of the Premier, 2014: Presentation 
to create employment and foster a socially cohesive better society for all KZN people.

The similitude between the issues identified at a national level in the NPC Diagnostic Report and those facing $\mathrm{KZN}$ at a provincial level is of note. This is no surprise, given that $\mathrm{KZN}$ is home to 10645509 people, the second largest province in terms of both its population (21.3\%) and its economic contribution of $16 \%$ to the national Gross Value Added (GVA), NPC Diagnostic Report (2011).

The NPC Diagnostic Report (2011: 7) states: "The continued social and economic exclusion of millions of South Africans, reflected in high levels of poverty and inequality, is our biggest challenge." This sentiment is echoed in $\mathrm{KZN}$, as indicated by the Situational Overview Report that was developed as a precursor to crafting of a new KZN PGDS. Hence, the fundamental challenge that the new KZN PGDS will need to address is creating more jobs for more people over a sustained time. The cornerstone of this challenge for $\mathrm{KZN}$ is twofold: first, to develop its large unskilled labour force and improve the quality of education of especially its Black, poor population to achieve educational outcomes aligned with the growth and development path and, secondly, simultaneously to build safe, healthy, and sustainable communities and livelihoods that are essential to maintain shared economic growth. The structural constraints to growth in $\mathrm{KZN}$ that have been identified are increasing unemployment, poverty, and inequality.

The KZN PGDS is fully aligned with the various chapters, objectives and actions of the NDP in order to address the abovementioned challenges (NDP 2030, 2012: 54). Only a few relevant challenges will be highlighted in this article. With regards to unemployment, the NDP requires an additional 11 million jobs by 2013 . Regarding transport and logistics infrastructure, the key focus of the NDP is the upgrading of the Durban-Gauteng freight corridor, including a new proposed dug-out port at the old airport site of Durban.
On transforming human settlements, the NDP spells out various objectives, including a strong and efficient spatial planning system across all spheres of Government, more people living closer to their places of work, and more jobs close to dense, urban townships (NDP 2030, 2012: 58). Actions flowing from these objectives include reforms to the current planning system for improved coordination, development of strategies for densification of cities and resource allocation to promote better located housing and settlement, and a national observatory for spatial data and analysis. Brooks (2013) maintains that these important focus areas have been considered and taken into account in the KZN PGDS and Provincial Growth and Development Plan (PGDP). The realisation of the KZN PGDS culminates in the implementation framework, as it significantly sets out priorities for the Province.

\subsection{Implementation framework of the KwaZulu-Natal Provincial Growth and Development Strategy}

In order to realise KZN's Vision, seven strategic goals and 30 objectives supported by 124 implementable interventions have been developed, as indicated in Figure 4 (KZN-PPC, 2011: 10, 178).

As highlighted in the illustration, in order to implement plans, Provincial Government Departments, of which there are 15 in $\mathrm{KZN}$, must work together with other spheres of Government and relevant agencies. The work of these departments is co-ordinated mainly through the four Cabinet Clusters: Economic Sector and Infrastructure Development, Social Protection, Human and Community Development, Governance and Administration and Justice, Crime Prevention and Security. They are made up of departments with similar interests to ensure alignment and co-ordination among each other with monitoring of these clusters to ensure integrated service delivery.

The 2011 KwaZulu-Natal Provincial Growth and Development Strategy (PGDS) is the primary strategy that drives growth and development in the province to 2030 (PGDS, 2012: 153-154). This strategy had been cascaded into a KZN Provincial Growth and Development Plan (PGDP), which guides the implementation of the PGDS. The aim of the PGDP is, therefore, to translate Strategy into a detailed implementation plan, inclusive of a detailed activity level framework with baselines, targets and assigned responsibilities, thus enabling execution of the proposed 124 interventions, 30 strategic objectives and seven strategic goals.

In addition to more detailed focus on interventions identified in the PGDS, the PGDP also set specific milestones to be achieved in specific priority sectors such as, but not restricted to, Education, Health, and Agriculture. This ought to be done in a collaborative approach with all the relevant stakeholders to ensure ownership of targets that will be set for four specific time horizons, namely 2011-2015, 2016-2020, 2021-2025 and 2026-2030. The KwaZulu-Natal Planning Commission facilitates and supports lead agencies to develop these detailed trajectories to ensure a clear roadmap to achieve the 2030 Vision for KwaZulu-Natal.

Whereas the PGDS will be reviewed every five years, or when a major event has a significant impact on the provincial growth path, the PGDP will be reviewed annually. The KZN Planning Commission facilitates preparation of half yearly progress reports submitted to Provincial Cabinet, as well as to all stakeholders via the above-mentioned institutionalised implementation structure. In giving long-term direction to municipalities beyond five-year periods of the Integrated Development Plan (IDPs), each District developed a District Growth and Development Plan with the same time horizon of the NDP and PGDS, namely up to 2030. The IDPs are, therefore, crucial for implementation of the PGDP.

It will be used for the five-year period of implementation as mentioned earlier, with effective monitoring and evaluation as an imperative of the Plan. 


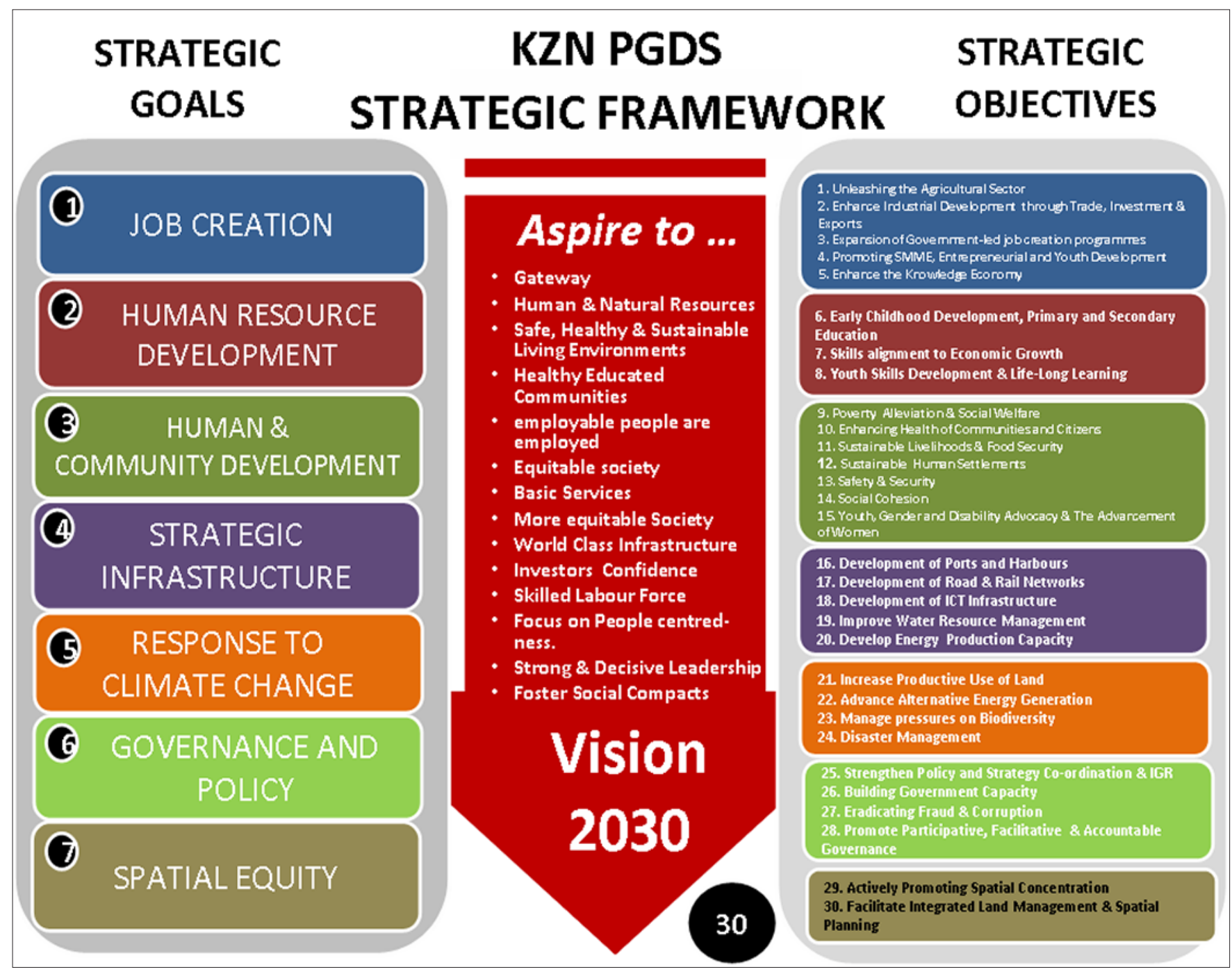

Figure 4: PGDS strategic framework

Source: KZN Office of the Premier, 2014: Presentation

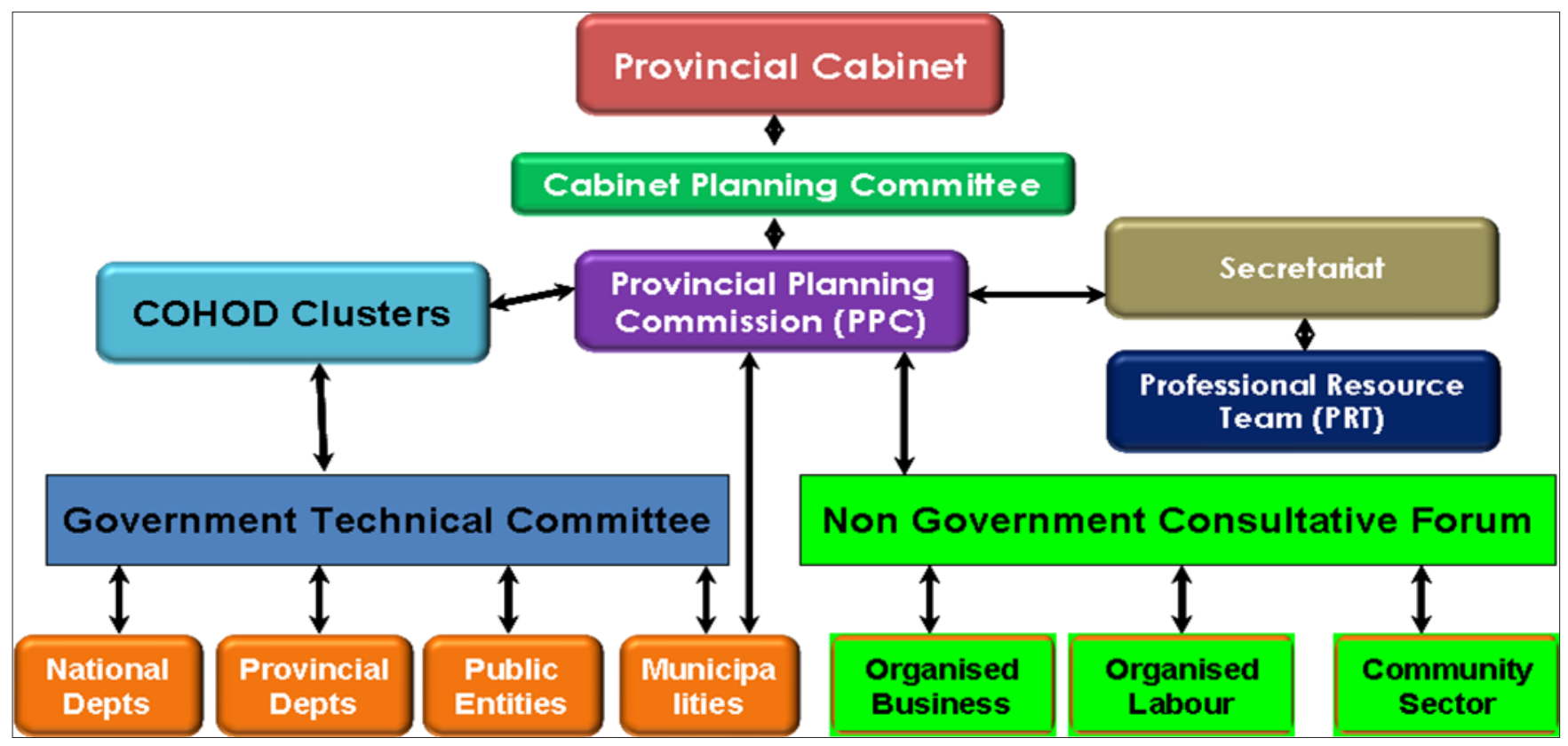

Figure 5: Depiction of Provincial Cabinet, Clusters and Provincial Planning Commission

Source: KZN-PPC, 2011: 18 


\section{ENHANCING DELIVERY THROUGH PROVINCEWIDE MONITORING AND EVALUATION SYSTEM}

Former President Thabo Mbeki unequivocally entrenched the notion of accountable governance in the form of target-driven service delivery in the May 2004 State of the Nation Address. Government has committed itself to effective service delivery and a set of development targets with clear timeframes. Successful achievement of these targets and the meeting of outcomes-based objectives, as planned and budgeted for in terms of the Medium-Term Expenditure Framework (MTEF), requires a collaborative and transparent national and provincial monitoring and evaluation system in support of both sound performance management and strategic management. At provincial level, service delivery is a top priority through the provincial strategy, maintains de Coning (2008: 87).

In view thereof that the KZN PGDS of 1996 failed because of the lack of a Monitoring and Evaluation Framework, a comprehensive monitoring and evaluation system was developed to ensure implementation across the 18 Action Work Groups (AWGs), convening departments, cabinet clusters, and co-ordinating councils.

\section{TOWARDS SPATIAL EQUITY IN PLANNING AND DEVELOPMENT}

To encapsulate the preceding discussion of a monitoring and evaluation framework, an example of the goal of PGDS linked to the DGDP is that of Goal 7 of the PGDS which demonstrates how spatial requirements of the NDP are being addressed through the DGDP and the Monitoring and Evaluation System. Furthermore, spatial equity is a significant aspect of planning and development, which is reflected within Goal 7 as part of KZN's key priorities, as illustrated in Figure 6.

The above figure refers to how the PGDP aims to achieve spatial equity through the work and programmes

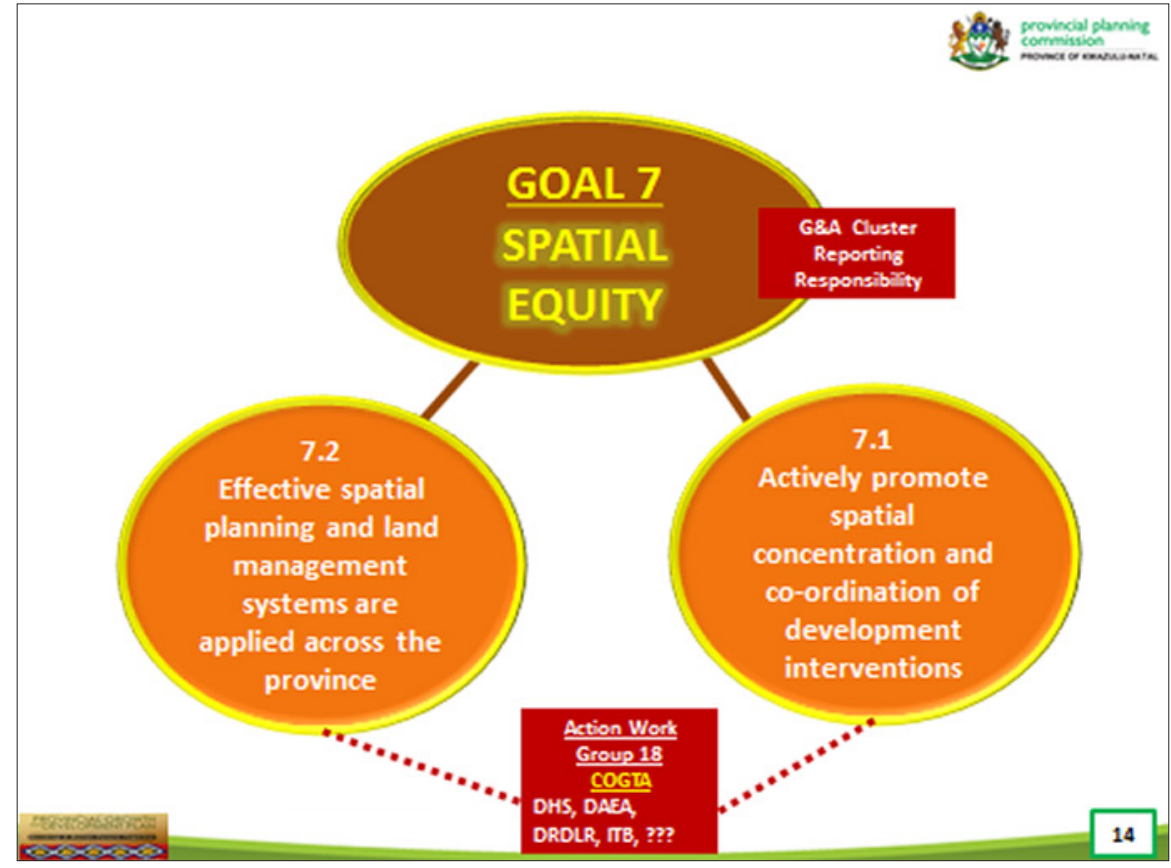

Figure 6: Goal 7 on spatial equity

Source: KZN Office of the Premier, 2014: Presentation

of the AWG in an attempt to increase spatial access to goods and services and improve physical access by the Spatial Equity/Accessibility Index. In essence, spatial equity aims to locate services at accessible and convenient places for residents and support through well-developed transport systems. Therefore, the NDP refers to new spatial norms and standards in densified cities, improving transport, locating jobs where people live, upgrading informal settlements, and fixing housing markets (NDP, 2012: 24).

AWG 18 that deals with Spatial Equity is implementing the NDP goals by undertaking programmes and projects guided by two strategic objectives, namely: to actively promote spatial concentration and co-ordination of development interventions and effectively apply spatial planning and land management systems across the Province. Various examples of interventions are listed to demonstrate the comprehensive nature of steps being taken by KZN to address the spatial equity and to meet NDP requirements focusing on the formalisation of strategic rural nodes: formalisation of 13 towns, including Jozini, Manguzi, and Mbazwana; densification of settlements such as Greater Kokstad and uMuziwabantu Municipalities; alignment of KZN Planning legislation with the SPLUMA; development of Traditional Settlement Master Plans, and formulation of DGDPs.

These interventions are monitored on a monthly basis by means of a pre-determined matrix, including progress with implementation, comments/recommendations, likelihood of achieving target, budget performance, job creation, and critical success factors. The proposal is also on the table to cascade the work of the 18 AWGs to that of municipal levels so that priority projects could be included into the IDPs and the implementation could be monitored.

President Zuma established two Ministries in the Presidency to strengthen both strategic planning and performance monitoring and evaluation (Coetzee, 2010: 21) as a national imperative for the country. The manner in which $\mathrm{KZN}$ has set the PGDP monitoring and evaluation system links up seamlessly with the national monitoring and evaluation system. 
8. SPATIAL PLANNING IN THE CONTEXT OF THE NATIONAL DEVELOPMENT PLAN: A 'NEW' PLANNING TRADITION

Spatial planning is constrained by developments and, at times, excludes the previously disadvantaged. Spatial development frameworks are, however, the most powerful tools available to spatial planners to integrate the dual space economy amidst the rich and poor, developed and underdeveloped. Although muted in the spatial planning process, IDPs are also useful strategic tools for spatial planning in service delivery, but the poor are continuously located far away from centres of employment.

Recently, there are efforts to move away from the old planning tradition of focusing on the organisation of space and the allocation of resources, to a new approach concerning human needs: economic, social, cultural, environmental and political aspects. Following on the concern with human needs, the new approach concentrates on the implementation of plans through the IDP. Factors such as the availability of financial, technical and managerial resources and skills, together with the capacity to implement both feasible and credible plans are gaining prominence amidst the NDP (Van Zyl, 2012: 23).

Haines and Robino (2006: 5) hold the view that areas such as institution-building, the 'ownership' of development policies, participation, social capital, human development, and sustainable development have been brought into the current focus through the NDP. This is a significant point worth noting in the discussion of the NDP and the contemporary focus of the planning discourse. The authors of this article maintain that there is a surplus of literature on the IDP and NDP, but not a great deal of attention is focused on linking the synergy between both and a contribution of knowledge contextualising their integration for enhancing service delivery.

\subsection{Integrated development planning (some contemporary perspectives)}

Madzivhandila and Asha (2012: 372)

state that, for developmental local government to become more effective in addressing poverty at grass roots level, it must be more innovative and creative in solving social problems. The key tool for enhancing the required innovative capacity of local municipalities is the IDP.

In this respect, good planning is integrated, since it takes into account diverse perspectives and impacts, allowing decision makers to find optimal solutions to critical issues, as well as effective ways to respond to those issues (Litman, in Gueli, Liebenberg \& Van Huyssteen, 2007: 93). Over the past number of years, it has become increasingly evident that development interventions with a strong sectoral emphasis are not sufficient to deal with the complexity of the developmental agenda. Instead, there has been a gradual shift toward the simultaneous, rather than sequential pursuit of diverse objectives, such as poverty eradication, gender empowerment, and provision of basic human needs, governmental transparency and accountability, and environmental sustainability (Gueli et al., 2007: 100).

Over the past two decades, planning has transformed significantly in South Africa - from the typical modernist planning system to a more postmodern, democratic, strategic, and developmental type of planning system. The contemporary planning system in South Africa was incidentally informed, to a large extent, by international planning trends that developed (Coetzee, 2012: 10).

Following on decades of learning, practising, and trial-and-error, planners and Government leaders still find it difficult to effectively implement the new planning system and to bring about change that is needed. COGTA (2009) argues that this slow progress has been the result of, among others, poor service delivery, poor governance, lack of leadership, weakening of institutional structures, as well as lack of capacity and skills (Coetzee, 2012: 14).

\subsection{Contextualising the Integrated Development Plan and the National Development Plan}

Coetzee (2012: 6) maintains that also criticised in a multitude of forums and through various assessments and reviews of IDPs; lack of a long-term vision and strategic focus can impact negatively on strategic plans. Furthermore, lack of focus on community needs and priorities; improper implementation and monitoring; ill-conceived integrated and sustainable development outcomes, and poor links between the IDP and the budget can have a negative impact on development (municipal tool versus planning and management tool). While many of these problems are ascribed to the rigid and cumbersome process of formulating IDPs and the challenges posed by the community participation phases, these problems are also ascribed to a lack of understanding of IDP principles and process; lack of capacity in local authorities (in both the IDP offices and sector departments); lack of managerial and political support and guidance from the top; lack of funds to manage and implement the process; poor and inappropriate organisational structures and lack of an IDP mindset and culture.

Parnell \& Poyser (in Subban \& Theron, 2012: 28) state that, in response to the changing political and socio-economic climate, new and demanding requirements have been placed on local governments worldwide. Municipalities have become increasingly relevant. Evidently, integrated development planning processes has introduced unprecedented challenges in municipal service delivery. Therefore, whilst the PGDS is being implemented, IDPs are formulated annually to be in line with the PGDS and NDP.

Again, as required by the Municipal Systems Act, the adopted 2014/15

Reviewed IDPs were assessed for legal compliance and quality 
in accordance with the KZN

IDP Assessment Guidelines.

The assessments were done in accordance with six National Key Performance Areas (KPAs), namely Basic Services, Municipal Transformation and Institutional Development, Good Governance and Public Participation, LED, Cross Cutting issues, including spatial frameworks, environmental issues and disaster management. Major findings and subsequent recommendations of the MEC for COGTA IDP Panel are included in the KZN 2012/2013 - 2016/2017

IDP Assessment Report, as reviewed in 2014/2015, and summarised hereunder.

\section{- Basic services KPA}

Virtually all the municipalities have indicated co-ordination of their development activities with the relevant sector departments and service providers. What is sometimes lacking, however, is that the role and responsibilities of municipalities vis-à-vis the sectors (i.e., water, transport and electricity) is not sufficiently clarified.

Generally, all municipalities have indicated existing human settlements, settlement corridors, nodes and towns on maps in the IDPs in order to visually present the status quo and to indicate areas of opportunities for further planning and development in municipalities. In order to enhance and improve planning for infrastructure, municipalities have to include in the IDPs the demands for infrastructure such as water, electricity and roads by the private sector as it has cost implications, but also provides development opportunities and job creation. IDPs, therefore, have to develop into a planning tool not only for Government, but also for the private sector at large.

In order to improve the basic services KPA, the following key recommendations were made relevant, and mapping should be included in the IDPs to illustrate planned basic services provision and infrastructure. Maps should also highlight areas of need and areas where service backlogs are evident. Sector Department projects for a municipal area must be clearly reflected in the IDP. In addition, municipalities must ensure that there is sufficient capacity to implement service delivery.

\section{- Municipal transformation and institutional development KPA}

The panel observed that some municipalities have attempted to fill critical posts whilst the challenge is predominantly in rural municipalities regarding attracting and retaining professional staff. Of concern is that many municipalities do not have a dedicated human resource team responsible for environmental management. In addition, there are municipalities who still do not have an Employment Equity Plan, Workplace Skills Plan or Human Resource Strategy in place. Various recommendations were made to improve the situation in municipalities regarding filling of critical posts and developing effective retention strategies. Municipalities need to take cognisance of the requirements of the Spatial Planning and Land Use Management Act, Act 16 of 2013 and facilitate the establishment of Municipal Planning Tribunals (MPTs) and the allocation of resources in terms of implementation of the Spatial Planning and Land Use Management Act (SPLUMA).

\section{- Local economic development KPA}

Some municipalities realised alignment to national and provincial policies and priorities. The majority of municipalities did not pronounce on the quantification on the number of jobs to be created in five years and annually. They failed to pay attention to social development priorities per ward.

\section{- Financial viability and financial management KPA}

Some municipalities were unable to spend their capital budgets whilst the majority of them were struggling to compile and implement revenue enhancement strategies. Furthermore, the majority of municipalities did not provide adequate information on the indigence level in the municipal area, did not have updated information on indigent support, and experience debt-collection challenges.

Recommendations include innovative revenue enhancement strategies, employee-related cost information in the IDP, spent on capital budgets, and KZN COGTA guidelines should be followed in addressing the issues of the indigent population.

\section{- Good governance and public participation KPA}

Some municipalities were silent about indigent policies. No proper linkage between the municipalities and their communities existed and no structures/plan relating to women, youth, the elderly, early childhood development, and HIV \& AIDS existed. Other observations include that municipalities did not separate the internal Audit Committee and Audit Committee, ineffective consultation with stakeholders and outdated bylaws, or lack thereof. IGR was ineffective in some municipalities, with others lacking a communication strategy. Recommendations include establishing Internal Audit and Audit Committees, prioritising review of all policies (including governance issues), as well as local municipalities need to improve their internal relationship with district municipalities. Traditional leadership engagements were proposed and communication strategies should be developed for municipalities.

\section{- Cross-cutting interventions KPA}

There was an improvement in the District and local Spatial Development Framework (SDF) alignment with the NDP and PGDP; cross-border planning and alignment was evident in some of the 2014 SDFs and municipalities are to be commended for such efforts. Some of the local municipal SDFs provided sound scheme development guidelines, as is called for in the MSA. Furthermore, SDFs lack a sound strategic focus and fail to integrate core aspects of the IDP into a strategic framework to guide transformation, appropriate 
investment and sound guidance on spatial development location in accordance with the long-term municipal vision. Recommendations include municipal planners and stakeholders carefully supported and capacitated in the development of strategically oriented visions, objectives, strategies, projects and programmes in the development of the SDF, and municipal planners be trained in development of capital investment frameworks. Implementation and institutional plans should be in accordance with the strategic focus of the SDFs, and municipal SDFs are required to make use of up-todate data sets available from the Department of Agriculture and Rural Affairs, STATSSA and other sector department's information.

Assessment of the quality of IDPs in $\mathrm{KZN}$ is an essential tool, first, for municipalities to improve the documents for more effective implementation and, secondly, for sector departments to align their programmes, projects and other critical information with the IDPs. Furthermore, the KZN PPC could see where the IDPs are heading in implementing its objectives. It is believed that the provision of public services through the various plans as discussed in the article, should heed the Principles of Batho Pele in order to avoid unnecessary friction and service delivery protests.

\section{PROVISION OF PUBLIC SERVICES}

According to Venter (in Mfene, 2009: 215), the notion of inter-organisational systems is supported, when it is argued that this inevitably entails a shift to a strategic mode of operation and greater decision-making authority being assigned to frontline officers. These are the employees who interact directly with citizens and other role-players. They require a number of accountability and transparency mechanisms to link everyday operations to the broader process of building an accountable culture. Implications of a wide scope of service is that, as public administration is the executive mechanism, public officials should take cognisance of the political, social and economic implications of the services rendered by all public institutions. The slow pace of service delivery by, for example, municipalities has led to growing impatience and discontent, especially among poor communities. This has been clearly demonstrated by the spate of uprisings in townships across South Africa directed at municipalities. The poor feel betrayed, because their active participation in government-provided opportunities for participation, such as elections, ward committees and IDPs has not resulted in visible improvement in the delivery of the promised services, asserts Theron (in Mfene, 2009: 221).

One of the outcomes identified by the State of the Nation Address in 2011 was a responsive, accountable, effective, and efficient local government system that is expected to improve service delivery, and is echoed in the current address and strategic intent of Government going forward.

Ultimately, Smith (in Subban \& Theron, 2011: 23) shares that the capacity of municipalities to meet financial and delivery commitments lies beyond political will, and rests, among others, on the willingness to invoke community participation in the affairs of local government for sustaining more effective local governance.

\section{PLANNING EXECUTED WITHIN THE CONTEXT OF BATHO PELE PRINCIPLES}

The Batho Pele Implementation Strategy (BPIS) of May 2014 will be used to evaluate whether planning is done ethically, accountably, and in a socially responsible manner, among others, to address poverty, inequality, and unemployment in line with the targets set out by the NDP, as highlighted in the foreground of this article. According to the BPIS, the following elements are relevant:

- Leadership and strategic direction;
- Consultation;

- Service standards;

- Access;

- Courtesy;

- Information;

- Openness and transparency;

- Redress;

- Best value for money;

- Encouraging innovation and rewarding excellence, and

- Service delivery impact

Against these Batho Pele principles, the locus of planning performance is contextualised and measured in the subsequent discussion in the article.

\section{- Leadership and strategic direction}

Evaluation cannot be done without scrutinising the drafting of the first PGDS for KZN from 1994 to 1996 (Theron, 2007: 89-160). In 1994, the RDP Office was tasked to give strategic direction to Government by developing a vision and assist provinces to formulate PGDSs. The KZN Cabinet gave a subsequent mandate to the KZN Economic Forum in conjunction with the Department of Economic Development to formulate the KZN vision and PGDS, adopted in June 1996. Whilst the Plan has been formulated, the Department of Local Government and Housing (DLGH), a predecessor of COGTA, also played a major role in finalising and implementing the Plan. The DLGH and KZNEF and DED formed an EXCO that guided the plan drafting and implementation.

A major drawback of the 1996 Plan was that departments worked in silos, was not prepared to adjust budgets in accordance with the PGDS priorities, and did not send mandated officials to PGDS meetings. When the responsibility of the review of the PGDS was shifted away from DLGH and DED to the Office of the Premier, the initial PGDS diminished until Provincial Cabinet resolved in 2010 that a new PGDS is needed to take the province forward. Strong leadership was demonstrated with the establishment of the KZN PPC that was made responsible for drafting the Plan within a year, namely 2011, with all stakeholders 
bound to the plan's formulation and implementation.

In order to implement the PGDS of 2011, 18 Action Work Groups were established with a dedicated chairperson and allocated objectives for reporting purposes. In this manner, the KZN Provincial Government is capable of playing a developmental and transformative role, among others, as required by the NDP (NDP 2030 Executive Summary, 2012: 64).

A core mandate of COGTA is to ensure a single 'window' of coordination and regulation of national, provincial and local Government (BP: 2). Consequently, COGTA is the COG of the wheel by standing at the centre of integrated development planning in the province. COGTA has to co-ordinate vertically and horizontally and do away with the silo approach by sectors. In conjunction with the PPC, COGTA has to align planning across the three spheres of government by strengthening the IDPs. COGTA also has to ensure that there is alignment of priorities of national and provincial departments implemented in the local space in IDPs. (BP: 3). KZN COGTA is, therefore, ensuring that the relations between all spheres of government are improved through a more proactive approach to managing the IGR system (NDP 2030 Executive Summary, 2012: 64).

There are various ways in which COGTA is fulfilling this comprehensive mandate. COGTA staff are members of the 18 Action Work Groups that are responsible for implementing and monitoring the implementation of the PGDP programmes and projects. Regular reports are drafted and submitted to the AWGs. COGTA oversees the financing and formulation of the ten District Growth and Development Plans (DGDPs). These Plans have the same 2030 time horizon as the NDP and KZN PGDS. COGTA is making certain that these Plans dovetail with the PGDP and the IDPs. One of COGTAs main responsibilities is to support municipalities with the formulation of IDPs. Where COGTA found that IDPs are wanting, the
IDP Co-ordination Unit assists these municipalities with additional support. Gaps are identified and municipalities are assisted to re-organise their IDPs in line with the IDP Framework Guide and Assessment Guidelines in order to improve the quality of the document and legal compliance.

COGTA acts in accordance with the Batho Pele strategy: "Leaders (have) to provide direction, create alignment, engage staff, create effective partnerships and demonstrate ethical and sound values" (GOGTA, 2014: 7). This echoes the stance of Richard Levin, Director-General of the Public Service Commission, who quoted Frantz Fanon's, 'The wretched of the earth', who stated the following (Levin, 2013: 67):

\section{Most importantly, we need exemplary, authoritative leadership that takes responsibility for building a new culture of Public Service Excellence based on outstanding ethics and people- centred delivery at all levels of the system. Without such leadership ... we are in danger of falling into the abyss ...}

Levin continued (Levin, 2013: 67) that leadership is needed to ensure that predetermined outcomes, outputs and targets are achieved, not simply for compliance purposes, but for excellent performance. Ethical transformational leadership should also be rooted in a commitment to hard work and perseverance and should reflect, on every possible occasion, a deep commitment to professionalism and integrity in the workplace.

\section{- Consultation}

COGTA cannot do its work if there is no consultation with municipalities. The Batho Pele Implementation Strategy states that COGTA has to take into account the views of the IDP Stakeholders (BP: 6). In this instance, the NDP states that leaders have to balance the power with responsibility, including listening to, and tolerating different and diverse views, and working together to resolve problems (NDP 2030 Executive Summary, 2012: 17). The consultation process commences with the updating of the IDP Management Plan (IDPManPlan) at the beginning of the year. The

Plan outlines critical actions, dates and responsibilities that need to be adhered to in order for the IDP formulation/review process.

The first step in drafting the Plan is for COGTA to set preliminary dates presented to the IDP stakeholders, namely municipalities, sector departments and State-owned Enterprises, in February for comment. The plan is further refined, with the final draft circulated again to stakeholders. At the annual Planning Indaba in September, the plan was adopted for implementation by guiding the IDP formulation process from September to July. The main clients of COGTA's IDP Co-ordination Unit are the municipalities, with the IDP Managers and Municipal Managers as entry points. The aim is to improve communication with stakeholders.

\section{- Service standards}

The BPIS states the following: “... making sure that the promised level and quality services are always of the highest possible standard" (GOGTA, 2014: 6). The MSA expects certain standards for the drafting of the IDPs. In order to ensure that the $60 \%$ credibility benchmark for IDPs is reached, an IDP Framework Guide for drafting IDPs and IDP Assessment Guidelines has been developed in conjunction with municipalities and other stakeholders. These guidelines are, in essence, the service standards for IDPs to ensure that KZN produces credible and legally compliant IDPs per the six national KPAs.

Important service standards are the manner in which COGTA confirms the receipt of the draft/adopted IDPs and Framework (FP) and Process Plans (PP). In view of the demands by Auditors, such correspondence has to be sent upon receipt of these documents. The IDP Unit does this in line with these requirements. The municipalities expect the letters within a reasonable time frame. The NDP refers to citizens having the right to hold leaders accountable for their actions (NDP 2030 Executive Summary, 2012: 17). This principle, is further expanded 
in the 'Back-to-Basics' approach during which communities should hold municipalities accountable for decent living conditions by delivering services consistently to the right quality and standard, including planning, delivery and maintenance of infrastructure and amenities (Pule, 2014: 61).

\section{- Access}

The IDP BU aims to be as accessible as possible for municipalities on IDP matters. Planning staff attend Municipal IDP Representative Forums as well as Planning and Development Forums held regularly by municipalities.

\section{- Courtesy}

The BPIS states: "treat (clients) with consideration and respect" (GOGTA, 2014: 6). In addition, the NDP indicates that the state should be developmental, capable and ethical in treating its citizens with dignity (NDP 2030 Executive Summary, 2012: 24). In addition, the My public servant, my future programme adds the important value of professionalism by civil servants to ensure an efficient service to the public. This principle links to what Minister Richard Baloyi and later Minister of Cooperative Governance and Traditional Affairs had said, namely, putting communities at the centre of public service planning and operations (Nkwamba, 2011: 51).

\section{- Information}

The IDP Unit does this by providing the correct information on time and paying regular visits to Municipalities. Where differences occur, especially regarding the IDP assessments and related scores, a mature discussion is necessary and conflict should be avoided. The IDP BU promotes access to information on services (GOGTA, 2014: 16). The Annual Performance Plan targets were discussed at the IDP de-briefing session. A long-standing practice is to place all the adopted IDP versions on the COGTA website. Annually, sector department staff are trained in-house on IDP-related matters, processes and contents. All relevant information related to the IDP process has to be available to stakeholders so that they can participate fully and make informed decisions.

\section{- Openness and transparency}

In this instance, clients must have all relevant COGTA reports (GOGTA, 2014: 17-18). COGTA will continue to place the IDPs and other relevant assessment reports on their website, including presentations made on IDP- and PGDS-related matters. The IDP will be open with municipalities regarding the shortcomings of the IDP Assessment Guidelines, and it needs a review in conjunction with all stakeholders. All these actions are in line with the NDP that highlighted that better communication, more honesty, and a greater degree of humility by those in power would go a long way towards building a society that can solve problems collectively and peacefully (NDP 2030

Executive Summary, 2012: 27).

This approach links directly with the aims of the (International) Open Government Partnership (Dlodlo, 2014: 42-43), of which South Africa is a voluntary member. This Forum agreed on the establishment of Service Delivery Improvement Forums in provinces at a local level. This will provide timely citizen report cards on service delivery at community level, especially in terms of primary healthcare, water, sanitation, environmental management, and housing (Dlodlo, 2013: 46). The South African Action Plan is based on good governance and an open society underpinned by values of transparency, accountability and participatory governance, the aim of which is to improve progressive implementation of the NDP (Dlodlo, 2014: 43).

\section{- Redress}

COGTA has to introduce redress mechanisms in view of the ongoing IDP assessments, such as feedback sessions on municipal level, individual visits, training and supporting the weak performers. A good IDP does not necessarily mean good service delivery. This brings into play the relationship between politicians and Heads of Departments
(HODs) (Hlope, 2013: 85). Political leaders face increasing pressure to steer their departments towards higher levels of performance. The citizenry is moving away from the expectation that a political leader delivers grandiose political speeches. Politicians are expected to be technically knowledgeable in the functions of the departments they lead. Often, in service-delivery protests, citizens expect to be addressed by political heads. In KZN, the MEC of COGTA works via the MUNIMEC to communicate quarterly with Mayors and Municipal Heads of Department to address servicedelivery concerns.

\section{- Best value-for-money}

Cost-cutting measures include assessing IDPs in-house, using Government facilities for alignment sessions, placing IDPs on CDs and avoiding unnecessary paper copies that are expensive and take up space prior to drafting reports, agreeing on the format to avoid wasting time and costs involved in printing the report and/or letters. Further cost reduction includes consultants for specialist tasks. Corruption should not be allowed (NDP 2030 Executive Summary, 2012: 46). COGTA supports and monitors KZN municipalities to implement the recently introduced 'Back-to-Basics programme' initiated by DGOG under the auspices of Minister Pravin Gordan (Pule, 2014: 60-61). Under this approach, local government spent public funds carefully to ensure sound financial management by prudently managing resources, so as to sustainably deliver services and bring development to communities. Wastage should be cut and corruption rooted out. It is submitted that knowledge is power in the fight against corruption (PALAMA, 2013: 36-37). Therefore, the National School of Government trained new public servants on the Public Service National AntiCorruption Strategy. Furthermore, public servants are challenged to live Batho Pele principles by instilling values, ethos, public service culture, and doctrines in order to achieve effective and efficient service delivery. 


\section{- Encouraging innovation and rewarding excellence}

These practices should continue the proper scoring and ranking of IDPs, the handing out of certificates and trophies at Indaba or world planning day and sustainable living exhibition. Those municipalities that use simplified IDPs should be commended, while best practices should be identified and presented at the Best Practice Conferences. Municipalities should also be recognised for drafting their IDPs in-house in order to give recognition to effective civil servants and boost in-house capacity (Timm, 2013: 51).

According to Mfene (2009: 216), it is submitted that all public officials should honour the guidelines to ensure that they and the public recognise universal social values. Although these principles are not necessarily quantifiable, they are value-related and as important as the service itself.

\section{- $\quad$ Service-delivery impact}

A closer link should be forged between the drafting of the IDP and the compilation of the Annual Municipal Performance Reports drafted to determine impacts per National KPAs per municipality. Service-delivery satisfaction surveys by municipalities and now by COGTA should be undertaken as a matter of urgency. The NDP wants everybody to enjoy a decent standard of living such as sufficient nutrition, housing, water, sanitation, electricity, transport, clean environment, and education (NDP 2030 Executive Summary, 2012: 28). The NDP-PGDP-IDP in the hierarchy of plans are the ideal vehicles to achieve these goals. According to De Coning (2008: 90), the emphasis on poverty requires a focus not only on basic service delivery and the wellbeing of communities, but also on economic participation and human development at all levels of Government and in all sectors and living spaces. Van Zyl (2012: 24) highlights that a more comprehensive approach to planning-in-practice is needed - an approach in which a clear distinction is made between synoptic planning (investigating matters and determining future action), and its long-term effects. This is premised on the intention of Government as envisaged in the NDP.

At the 2013 Government Leadership Summit (Pule, 2013: 85) under the auspices of the Ministry of Public Service and Administration, the then Minister in the Presidency responsible for the NPP, Trevor Manuel, stated unequivocally:

\begin{abstract}
... the time for blame games was over and civil servants needed to roll up their sleeves and render services to the public ... Nineteen years into democracy, our government has run out of excuses. We cannot plead ignorance or inexperience. For almost two decades, the public has been patient in the face of mediocre services. The time for change, for ruthless focus on implementation has come.
\end{abstract}

Through a national imperative for monitoring and evaluation in the country, linking PGDP in KZN would assist in tackling the new challenges and development planning work procedures, thus ensuring that IDP priorities are addressed in an integrated manner. The intent is viable approaches to ensure that transformation is geared at improving the lives of all people, as envisaged in the strategic intent of the NDP.

From the above discussion, it can be stated that, in order to provide a better understanding of the challenges facing local government and the role of municipal planning in the development process, the developmental state model, which in recent years informed development thinking and processes, can be realised through a closer synergy in aligning the NDP to all integrated planning levels.

\section{CONCLUSION}

While policy frameworks inform planning processes, the authors conclude that the IDP and NDP are inextricably linked in addressing the developmental agenda of local government and in strategically taking the planning discourse to new heights in KZN. Municipalities and the provinces rely on the theoretical and practical realities of contemporary planning, while aligning these developments in a socially responsible manner to enhance service delivery. In essence, tracing the socio-economic context of development planning from a position of 'underdevelopment' to development planning within the national strategic intent of the PGDS and the NDP cannot be overemphasised in the present planning era. The authors advanced the nexus of planning-in-practice in the alignment of the NDP-PGDPIDP. The article examined how KZN observed innovatively the planning ambit amidst the ethical, accountable, and moral agenda necessary for addressing poverty, inequality and unemployment. It is submitted, as reiterated earlier in the article, that theory without practice is stagnant and practice without theory is visionless. This is appropriate to planning and reflective of ongoing attention, in the post-apartheid era, to enhanced service delivery and sustainable development. Key recommendations emerged: the need for basic services; transformation as an essential outcome of local participation of communities in the IDP processes; necessity for local economic development as empowerment incentives; financial planning to support IDP priorities, which ultimately contribute to good governance in service delivery. Addressing the Batho Pele principles in an integrative manner with the development agenda ultimately provides a more holistic approach to socially inclusive development and planning in the province of KZN.

\section{REFERENCES LIST}

BROOKS, F.R. 2013. Presentation. (Senior General Manager: KZN Provincial Planning Commission). Pietermaritzburg.

COETZEE, J. 2010. Not another night at the museum: 'Moving on' - from 'developmental' local government to 'developmental local state'. Town and Regional Planning Journal, issue 56, pp. 18-26.

COETZEE, J. 2012. The transformation of municipal development planning in South Africa (post-1994): Impressions and impasse. Town and Regional Planning Journal, issue 61, pp. 10-20. 
DE CONING, C. 2008. Policy review and the Provincial Growth and Development Strategy in the Western Cape. Africanus, 38(2), pp. 77-94.

\section{DEPARTMENT OF LOCAL} GOVERNMENT AND TRADITIONAL AFFAIRS (COGTA). 2014. Batho Pele Implementation Strategy (BPIS). Presentation.

DLODLO, A. 2013. A better government through openness. Public Sector Manager, May 2013, pp. 44-46.

DLODLO, A. 2014. An open

Government for accelerated development. Public Sector Manager, January 2014, pp. 42-43.

DREWES, E. \& VAN ASWEGEN, M. 2013. National planning in South Africa: A temporal perspective. Town and Regional Planning, issue 62, pp. 21-28.

GUELI, R., LIEBENBERG, S. \& VAN HUYSSTEEN, E. 2007. Integrated development planning in South Africa: Lessons for international peacebuilding? African Journal on Conflict Resolution, 7(1), pp. 89-112.

HAINES, R. \& ROBINO, C. 2006. A critical review of selected topics in development theory and policy in the Eastern Cape, South Africa. Africanus, 36(1), pp. 2-22.

HLOPE, D. 2013. Tensions between politicians and administrators: What is to be done? Public Sector Manager, June 2013, pp. 84-86.

KWAZULU-NATAL (KZN) 2012/20132016/2017 IDP Assessment Report, as reviewed in 2014/2015, October 2014.

KWAZULU-NATAL (KZN) COGTA. 2014. Presentation, Technical Munimec, PGDP Cluster Reports, 9 July 2014.

KWAZULU-NATAL OFFICE OF THE PREMIER. 2014. Presentation, KwaZulu-Natal key priorities for the term 2014/2019 towards 2030 , 25 Augustus.

KWAZULU-NATAL - PROVINCIAL PLANNING COMMISSION (KZNPPC). 2011. KwaZulu-Natal Provincial Growth and Development Strategy (KZN PGDS).

LEVIN, R.M. 2013. Corruption: Changing wicked ways in and outside of Government. Public Sector Manager, January, p. 67.
LUKHELE, T.M. 2015. The practical implementation of the policy frameworks that guide the planning and design of human settlements in the South African developmental state. Journal of Public Administration, 40(4), pp. 775-787.

MADZIVHANDILA, T.S. \& ASHA, A.A. 2012. Integrated development planning processes and service delivery challenges for South Africa's local municipalities. Journal of Public Administration, 47(1.1), pp. 369-378.

MFENE, P.N. 2009. A service delivery perspective on Public Administration. Journal of Public Administration, 44(1.1), pp. 209-221.

MULLER, J. 2012. Roots and routes: Twenty-five years of planning theory. Guest editorial. South African Institute of Town and Regional Planners. Pretoria, pp.1-3.

\section{NATIONAL DEVELOPMENT PLAN} (NDP). 2030. Executive Summary, undated.

NKWAMBA, D. 2011. Leading the march towards a clean and responsive public service. Public Sector Manager, November, pp. 49-51.

PADAYACHIE, R. 2012. The developmental state: New ideas for the public good. Public Sector Manager, March, pp. 44-48.

PALAMA. 2013. Courses to keep public servants on the straight and narrow. Public Sector Manager, January, pp. 36-37.

PENDERIS, S. 2012. Interrogating the emerging South African developmental state. Africanus, 42(1), pp. 4-15.

POWELL, D. 2014. The National Development Plan Vision for 2030. A good plan, but what happens to it now? Local Government Law Bulletin, 14(1), pp. 8-9.

PROVINCIAL GROWTH AND DEVELOPMENT STRATEGY (PGDS). 2012. Kwazulu-Natal Office of the Premier, Provincial Planning Commission, Provincial Growth and Development Plan.

PULE, A. 2013. Professionalising the civil service. Public Sector Manager, May, pp. 84-85.

PULE, A. 2014. Back to basics for local government. Public Sector Manager, November, pp. 60-61.
REPUBLIC OF SOUTH AFRICA (RSA). 1997. White Paper on Transforming Public Service Delivery (Batho Pele White Paper). Pretoria: Government Printer.

SUBBAN, M. \& THERON, H. 2011. Shared services for enhancing municipal planning efficiency in KwaZulu-Natal. Town and Regional Planning, issue 58, pp. 17-24.

SUBBAN, M. \& THERON, H. 2012. Tracing a decade of drafting, reviewing and assessing integrated development plans in KwaZulu-Natal: Some key reflections. Town and Regional Planning, issue 61, pp. 21-29.

TERREBLANCHE, S. 2014. Verdeelde land hoe oorgang in Suid-Afrika faal. Kaapstad: Tafelberg.

THERON, J.H. 2007. Lessons from the Strategic Management of Integrated Development Planning in KwaZuluNatal from 1996 to 2006. Unpublished $\mathrm{PhD}$ thesis, Bloemfontein.

TIMM, S. 2013. NDP transforms rural development landscape. Public Sector Manager, January, pp. 50-51.

VAN ZYL, G.N. 2012. Broadening the scope of planning. Sabinet reproduced. Originally published in Town and Regional Planning, issue 15(1983), pp. 23-24. 